\title{
A SILVER CROSS-RELIQUARY AND ITS PATRONESS IN TWELFTH-CENTURY RURAL ASTURIAS*
}

\author{
POR \\ JESÚS RODRÍGUEZ VIEJO ${ }^{1}$ \\ University of Aberdeen
}

\begin{abstract}
The cross-reliquary of San Salvador de Fuentes is a luxury crucifix in wood and silver created in the late twelfth century for this parish church of the Villaviciosa area, along the central coast of Asturias. The object has been in the Metropolitan Museum of Art in New York since 1917. The main aim of this contribution is to initially analyse the symbolism of the object's iconographic components to then examine its liturgical roles, paying special attention to the patroness of the cross, the noblewoman Sancha, and the perception of this precious performative reliquary in her local community.
\end{abstract}

KEY WORDS: cross-reliquary; Romanesque; female patronage; liturgy; performance.

\section{UNA CRUZ-RELICARIO DE PLATA Y SU COMITENTE EN LA ASTURIAS RURAL DEL SIGLO XII}

\section{RESUMEN}

La cruz-relicario de San Salvador de Fuentes es un suntuoso crucifijo hecho principalmente de madera y plata creado a finales del siglo XII para esta importante parroquia del concejo de Villaviciosa, en Asturias. El objeto es propiedad del Metropolitan Museum of Art de Nueva York desde 1917. El objetivo del presente trabajo es el de analizar el simbolismo iconográfico y los usos litúrgicos del crucifijo para luego contextualizar el patronazgo de la comitente del objeto, la noble local Sancha, y la creación de este relicario en la vida religiosa de la zona.

PALABRAS CLAVE: cruz-relicario; Románico; patronazgo femenino; liturgia; función.

CitATION / Cómo CITAR ESTE ARTículo: Rodríguez Viejo, Jesús. 2021. "A Silver Cross-Reliquary and its Patroness in TwelfthCentury Rural Asturias". Hispania Sacra LXXIII, 147: 115-124. https://doi.org/10.3989/hs.2021.011

\author{
Received/ Recibido 22-10-2019 \\ Accepted/Aceptado $\quad 07-05-2020$
}

Processional crosses and crucifixes are emerging in recent art historical discourses as precious performative tools that had a fundamental importance in the liturgy of the medieval Christendom and in the lives of pious individuals across Europe. ${ }^{2}$ Initially classified and described based on

* Funded by a DAAD Grant (2020) at the Institute for Art History, Goethe-University of Frankfurt am Main, under the supervision of Professor Kristin Böse. I am extremely grateful to Dr. Álvaro Solano Fernández-Sordo (Oviedo) for the help in approaching the history of the town of Villaviciosa.

1 jesus.rodriguezviejo@abdn.ac.uk

ORCID ID: https://orcid.org/0000-0003-2744-0279

2 Recent publications that explore processional crucifixes as well as representations of crosses in the Latin West are De Blaauw 2001; Saxon 2012, 274-276; Munns 2016 and Kitzinger 2019. their shapes, decoration, and provenance, many of these unique objects were later sidelined from academic interest and overshadowed by other media, still remaining today largely unknown to the wider public. Nonetheless, in the methodological approaches of current scholarship the liturgical functions and the original perceptions of these often luxurious devotional objects have re-appeared as the key to assess an immense corpus of artworks. These crosses were once at the centre of the religious life of entire communities and were generally the result of complex initiatives of patronage. $^{3}$

3 The single most important contribution is Walker-Bynum 2011, although focused on the late medieval period. 
High-ranking civil and ecclesiastical patrons and patronesses invested heavily in sumptuous art objects such as processional crosses as liturgical ex-votos with clear aims of societal prestige and as a posthumous memoria with a salvational component. ${ }^{4}$ While actual portraits are overall rare in the Early Middle Ages, such as the two cloisonneé enamel images on the respective crosses commissioned by Abbess Mathilde of Essen in Ottonian Germany (c. 1000), patrons more often requested short inscriptions of devotional nature displaying their names. The identities and religious interests of these donors were thus paraded and exhibited in countless occasions after the creation of the objects in question, remaining precious items in the inventories of local ecclesiastical institutions thereafter.

In more exceptional cases, the will of a high-ranking individual to associate his or her patronage with the liturgy of the community collided into a more specific religious interest with even more important repercussions at local level. The cult of saints and the veneration of relics helped to shape civic identities everywhere in the European Middle Ages and has defined to a large extent, often to this day, the liturgical customs of cities, parishes, and monastic communities. ${ }^{5}$ Hagiography and reliquaries occupied a central position in the liturgy of the early medieval Iberian Peninsula in particular. ${ }^{6}$ The so-called Mozarabic liturgy, or Old Hispanic rite, favoured the regular reading of passiones and other hagiographical materials as a way to exalt the saint's mediatory action and likely imitatio role models in the minds of churchgoers. Hagiography also acted as propaganda for local churches when a special connection, such as the ownership of a specific relic, existed. Although the Mozarabic rite was gradually replaced in Iberia by the Roman liturgy (especially after the king-sanctioned Council of Burgos in 1080), relics and reliquaries of all sorts still played a central role in the lives of medieval Spanish and Portuguese cities, monasteries, and parishes as the cult of saints boasted an allure over the population that resisted to die out.

The silver crucifix-reliquary of San Salvador de Fuentes (New York, Metropolitan Museum of Art, Acc. N. 17.190.1406) was commissioned by an Asturian noblewoman, Sancha, in the second half of the twelfth century (Fig. 1). She requested the cross for the eponymous parish next to the burgeoning town then called Maliayo (modern Villaviciosa). ${ }^{7}$ The permanent repository of the reliquary was the local church, San Salvador de Fuentes, a basilica founded in the early eleventh century with one central aisle and large apse, as well as perhaps minor lateral aisles back in the Middle Ages (Fig. 2). ${ }^{8}$ The church was officially dedicated by the Bishop of Oviedo and enjoyed an important position amidst a growing number of ecclesiastical foundations in the valleys surrounding what later became the town

\footnotetext{
4 The concept of memoria and liturgical art has been well studied in the case of Ottonian Hildesheim. See Kingsley 2011 and 2014.

5 Brown 1981, 62-70.

6 Bibliography is overall still scarce today in Spanish and highly localised. See Martín Ansón 1994; Silva y Verástegui 2009 y García de la Borbolla 2014.

7 Moralejo Álvarez 1982; Álvarez Martínez 1993; Little 1993; Little, Dodds, and Williams 1993, 271-272; Kawamura 1994; Cid Priego 1996, 480-486; Balbín Loredo 1996; Franco Mata 2009-2010; Morais Morán 2013.

8 Ruiz de la Peña 2001, 358, 364.
}

of Villaviciosa, together with the pre-Romanesque royal monastic foundation of San Salvador de Valdediós, barely one kilometre away from Fuentes. ${ }^{9}$

\section{FIGURE 1}

\section{Frontal View of the Fuentes Cross}

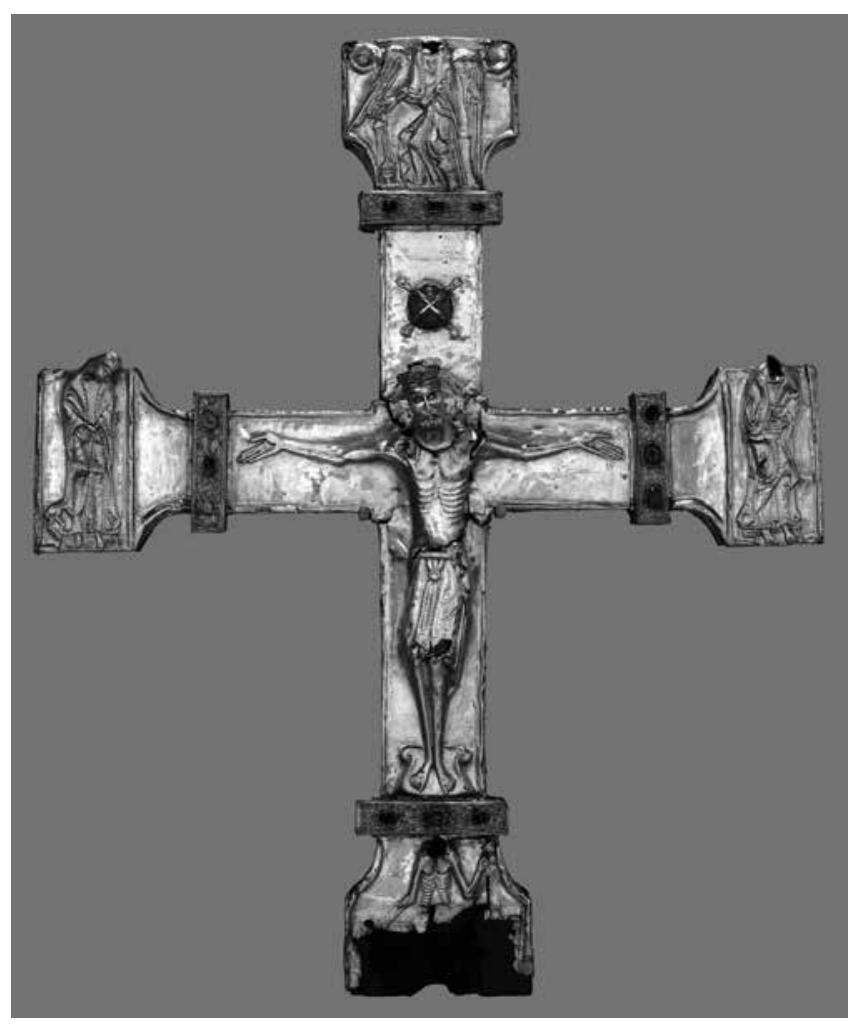

(C) Metropolitan Museum of Art, New York.

Measuring $59.1 \times 48.3 \mathrm{~cm}$, the wooden core of the Fuentes Cross was covered with silver plaques. ${ }^{10}$ The figure of Christ was made through repoussé, virtually as a high relief in the upper half of the body (Fig. 3). Christ shows two gems acting as eyes, his feet resting on a suppedaneum, while he wears a gilded crown with embedded stones. Behind Christ's head the artists designed a haloed cross, later gilded. The crucifix also displays on each of its four terminals the representations in repoussé of Mary (to viewer's left), St John (to the viewer's right), an angel with a thurible at the top flanked by Sol and Luna, and the figure of Adam, now largely damaged without his head, at the bottom (Figs. 1, $5,6)$. The recto of the crucifix also displays on all four terminals gilded filigree bars that originally contained a triad of engraved precious stones each. Only two stones in total, dating probably from Roman or Late Antique times and displaying a Niké with a wreath and a portrait of a man with a fish and a spear, survive. ${ }^{11}$ On the retro of each terminal, the artists conceptualised the four symbols of the Evangelists together with identificatory inscriptions made through repoussé and later gilded (Fig. 4). In addition to the eagle of St John (top), St Mark's lion (left), and St Luke's winged ox

\footnotetext{
9 Fernández Conde 1994; Arbeiter and Noack-Haley 1999, 175179, 192-203.

10 Little, Dodds and Williams. 1993, 271.

11 Ibidem 272.
} 
(right), the angel of St Matthew was originally displayed at the bottom but is now entirely gone due to severe damage, perhaps due to a fall. Vegetal motifs also in repoussé connect these four terminals to the centre of the reverse of the crucifix, where the artists created and gilded a representation of the Agnus Dei, now also substantially damaged.

\section{FIGURE 2}

Fuentes Cross, detail of Christ's figure

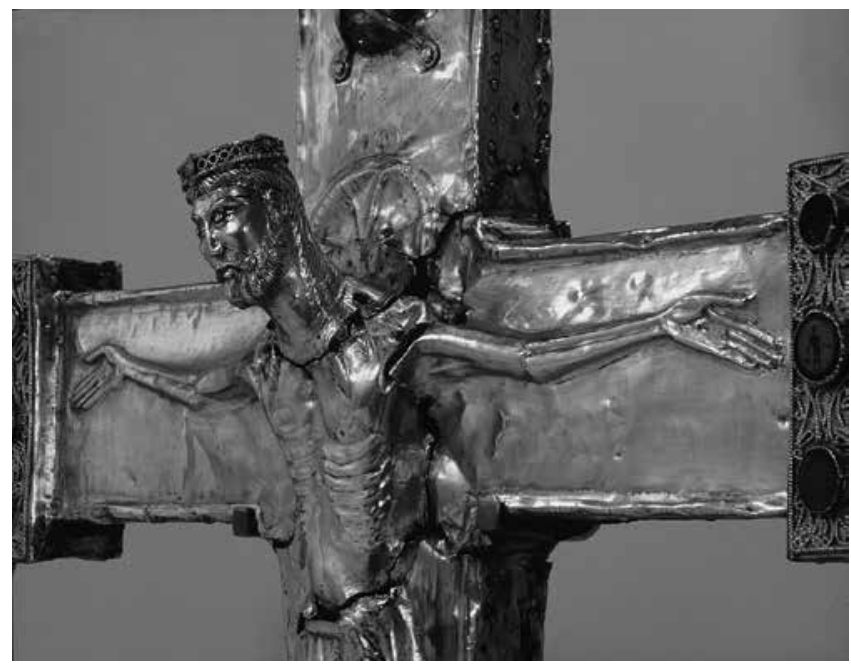

(C) Metropolitan Museum of Art, New York.

FIGURE 3

Rear view of the Fuentes Cross

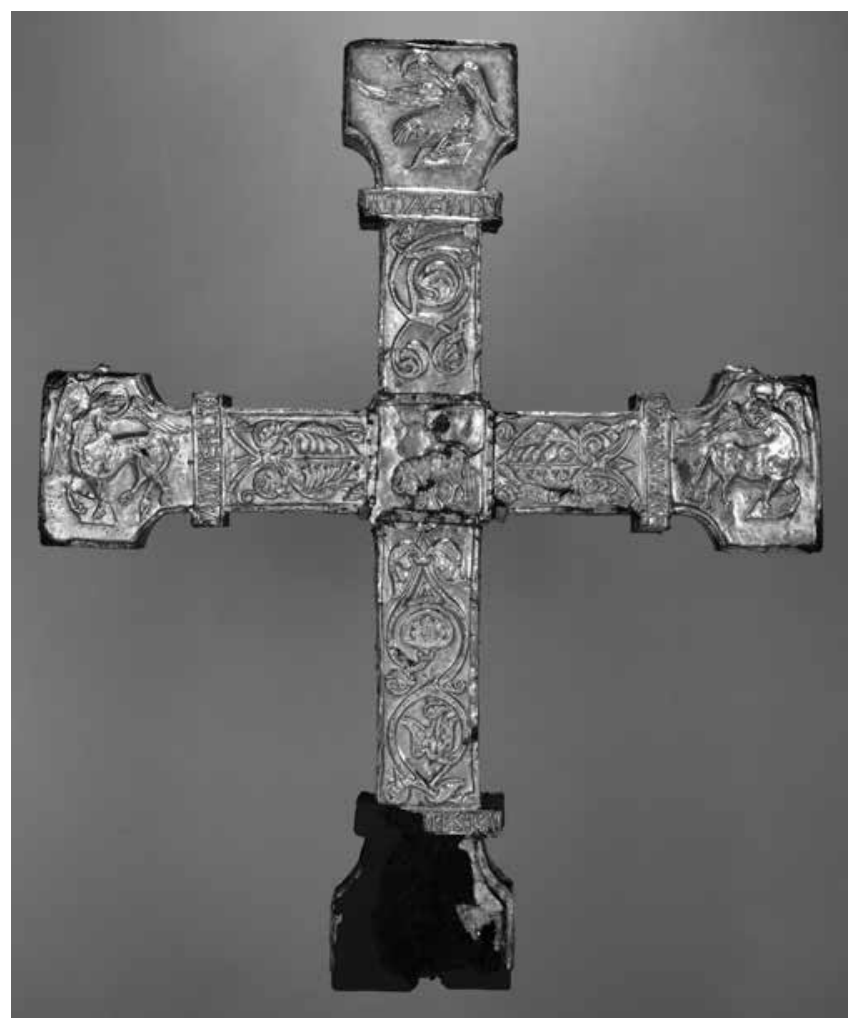

(C) Metropolitan Museum of Art, New York.

It is also on the retro of the object where the makers left a written message on behalf of the patroness. On each of these four gilded filigree bars, the letters of a devotional inscription read: "[IN HO]NORE S[AN]C[T]I SA/LVATORIS SA/NCCIA GUIDIS/ALVI ME FECIT". ${ }^{12}$ The message highlights the piety of a well-to-do Asturian noblewoman, Sancha Gundisalvo (or "Gonzalo"), towards the redeeming figure of Christ. A priori, the embodiment of that devotion was the silver crucified character itself. However, a round rock crystal above the figure of Christ covers a cavity carved into the wood that still today hosts an unidentified relic wrapped in a tissue. Although it is entirely impossible to confirm that this small relic was inserted as part of Sancha's initiative, the silver bands that hold the rock crystal do not show evidence of being a later addition. This scenario therefore facilitates conceiving the manufacture, handling, and reception of the silver crucifix-reliquary now in New York in the Asturian rural landscape of the late twelfth century.

This research will firstly examine the complex interplay of meanings that the several figurative contents of the crucifix had for their medieval audiences, to then shift to discuss the liturgical celebrations in which the Metropolitan crucifix likely played a central role and the physical settings for its use, such as the Church of San Salvador at Fuentes. Finally, this contribution will also contextualise the creation of this luxurious liturgical instrument and the patronage of Sancha by shedding light on the role and aspirations of local noble families in the parish of Fuentes and neighbouring rural ecclesiastical centres, as well as the importance of the cult of relics during this period of growth and wider interconnections in the Villaviciosa area.

\section{MESSAGES IN MOTION}

Academic interest in early medieval crosses has gradually shifted in past decades from the subjective spheres of descriptive analysis, styles, and provenance, to focus instead on reconstructing actual liturgical roles. Sible de Blaauw's 2001 contribution "Following the Crosses" and Annika E. Fisher's 2006 book chapter "Cross Altar and Crucifix in Ottonian Cologne" have enormously contributed to this change of perceptions. ${ }^{13}$ Fisher's research in particular examined one of the earliest surviving examples of a crucifix displaying Christ - the celebrated Gero Cross. Created around the year 970 , the Gero Cross was likely commissioned by the Cologne archbishop Gero (969-976) to be displayed inside Cologne Cathedral, perhaps somewhere along the central aisle of the building, such as at the chancel arch, or inside Gero's own funerary side chapel. The natural assumption of Fisher is that the Gero Cross was hung and permanently still. The reason is perhaps the rare description of the object given by the Ottonian author Thietmar of Merseburg years later in his Chronicon (1012-1018), which described a miracle that happened inside the funerary chapel of the former archbishop inside which the crucifix was hanging. ${ }^{14}$ Fisher's contribution therefore focuses on the correlation between the altars inside Cologne Cathedral (whether above the main altar or above the smaller chapel's presumed amenities) and the symbolic presence of the crucified character,

12 Ruiz de la Peña 2001, 358

13 See Blaauw 2001; Fisher 2006, 43-62.

14 Ibidem 45-46. See also Warner 2001. 
FIGURE 4

Fuentes Cross, figures of Mary and St John

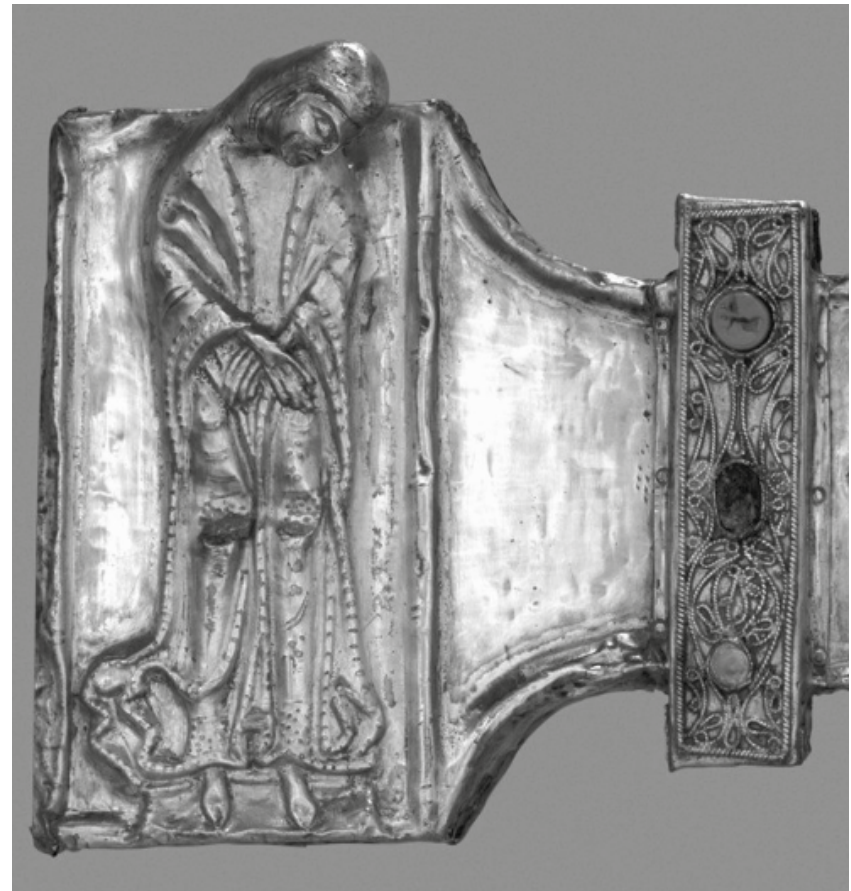

(C) Metropolitan Museum of Art, New York.

especially during the Mass. ${ }^{15}$ The visualisation of the Crucifix, according to Fisher and paramount exegetical sources from the early medieval period, such as Paschasius Radbertus, aided in the performance of the Eucharistic rituals at the altar by reinforcing the meaning of the ingestion of the Host in particular.

Two hundred years later or so, the Fuentes crucifix represented a very different case. Even though the presence of the hanging Christ established an unavoidable link to the performance and symbolism of the Mass, the richness of the iconographic programme of the New York crucifix added deeper layers of understanding to the meaning of its ceremonial role at Fuentes. An analysis of the object's imagery today therefore depends on the permanent position and occasional movement to which the cross was subject to. During the regular Eucharistic liturgy at Fuentes, perceiving the shining representations of the Crucifixion of Christ and other accompanying figures likely generated certain emotions and expectations among attending audiences.

No sorrow was visible in the expression of the silver Christ. However, the presence of Mary and St John amplified the redeeming message of the Crucifixion by offering an extended visual narrative to pious viewers when the cross was frontally displayed. If the figure of Mary at Fuentes, lowering and crossing her arms, alluded to both maternal sorrow and the acceptance of Christ's fate, St John acted as a witness of the events by exhibiting a book. For the learned and the attentive congregation that listened to the Mass readings, the message then recorded, as part of the Gospels, exalted Christ's death on the Cross and his existence as logos, or God's Word.

\footnotetext{
15 Ibidem 51-56.
}

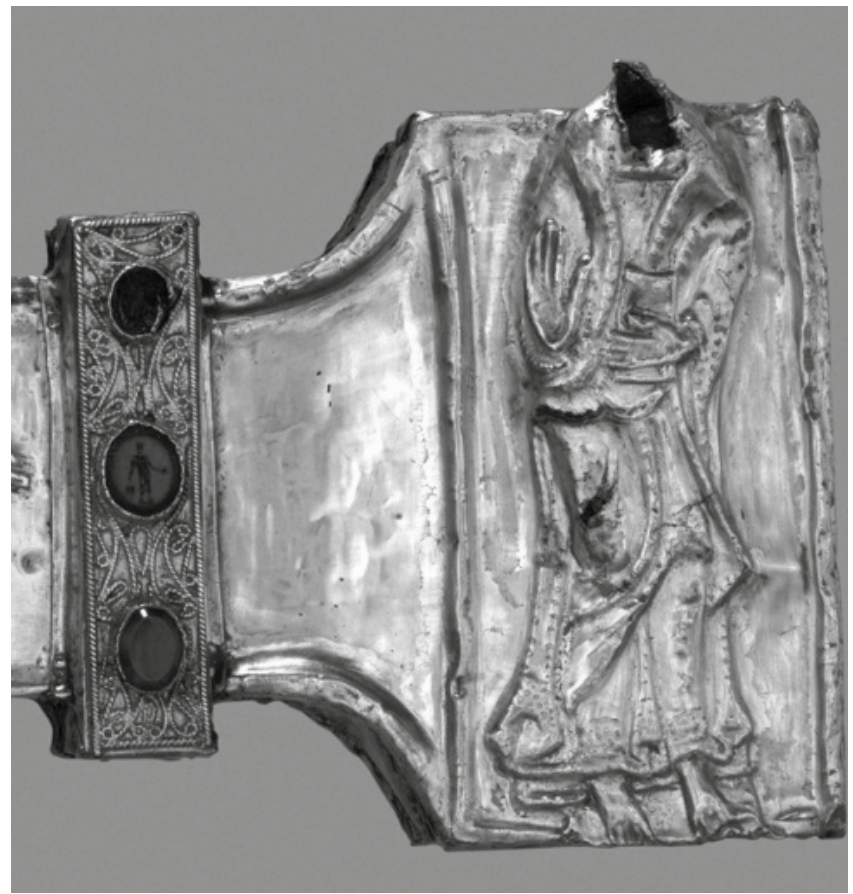

FIGURE 5

Fuentes Cross, Angels with thurible (and the relic's cavity below)

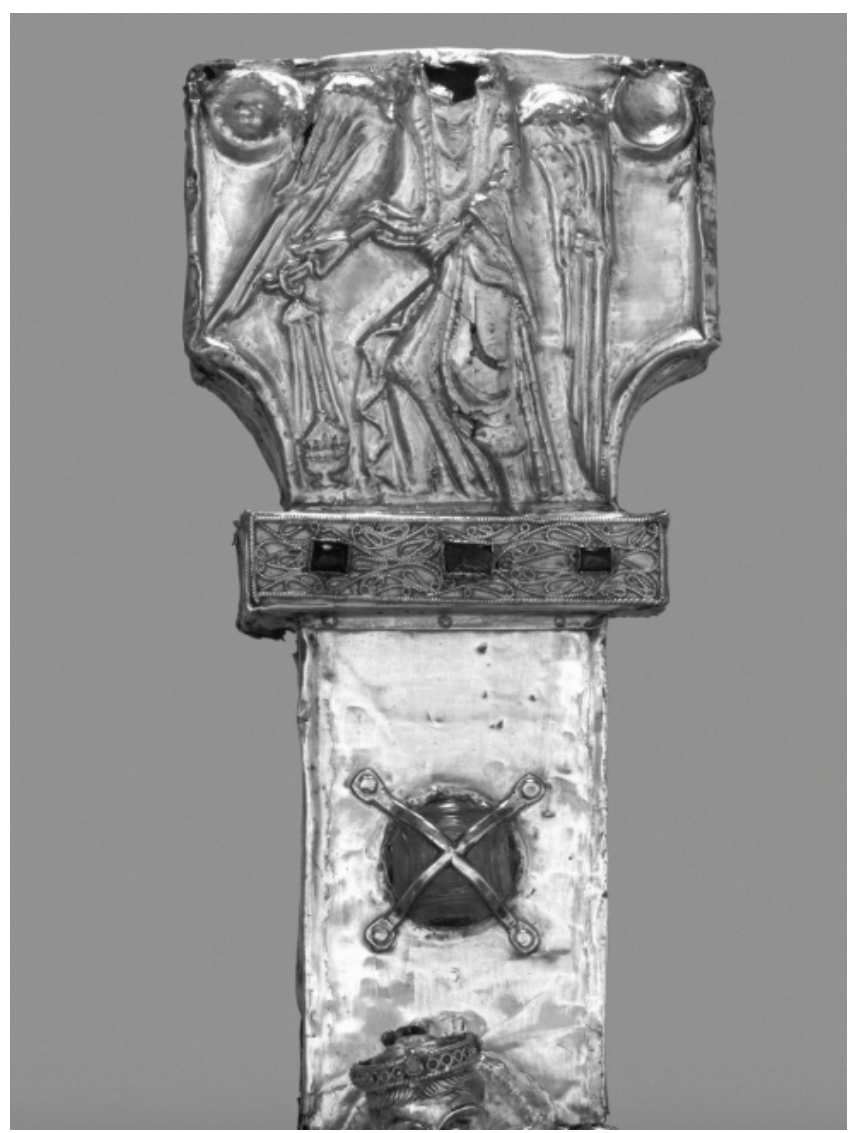

C Metropolitan Museum of Art, New York 
On the upper arm of the cross, an angel wielding a thurible witnesses the scene flanked by Sol and Luna. The angel's attribute drew a clear parallel with the real-life objects potentially used by priests or visiting bishops in the regular Mass ceremonies of the Fuentes parish or the Villaviciosa area, perhaps on special feasts such as Christmas or throughout the Paschal Triduum. ${ }^{16}$ In modern times, three double swings came to mark the display of an image of Christ and two double swings are performed when the relic of a saint, such as that inside the Fuentes Cross, was venerated. An even closer association appears between this thurible and the retro of the crucifix, where the Agnus Dei and the four symbols of the Evangelists are displayed. In the Book of Revelation, St John of Pathmos mentioned: "An angel, who had a golden censer, came and stood in front of the altar [...]. The incense, together with the prayers of the People of God, went up before Him from the hand of the angel". ${ }^{17}$ This angelic character seemed to have had an additional meaning, in relation to the retro of the cross-reliquary, where some of the most famous visions described in the Book of Apocalypse were seen by the congregation. As it shall be explained later, this perception originally stemmed from the movement of the object forwards, which allowed the figuration to be seen in a certain order.

\section{FIGURE 6}

Fuentes Cross, Detail of the Suppedaneum and Adam

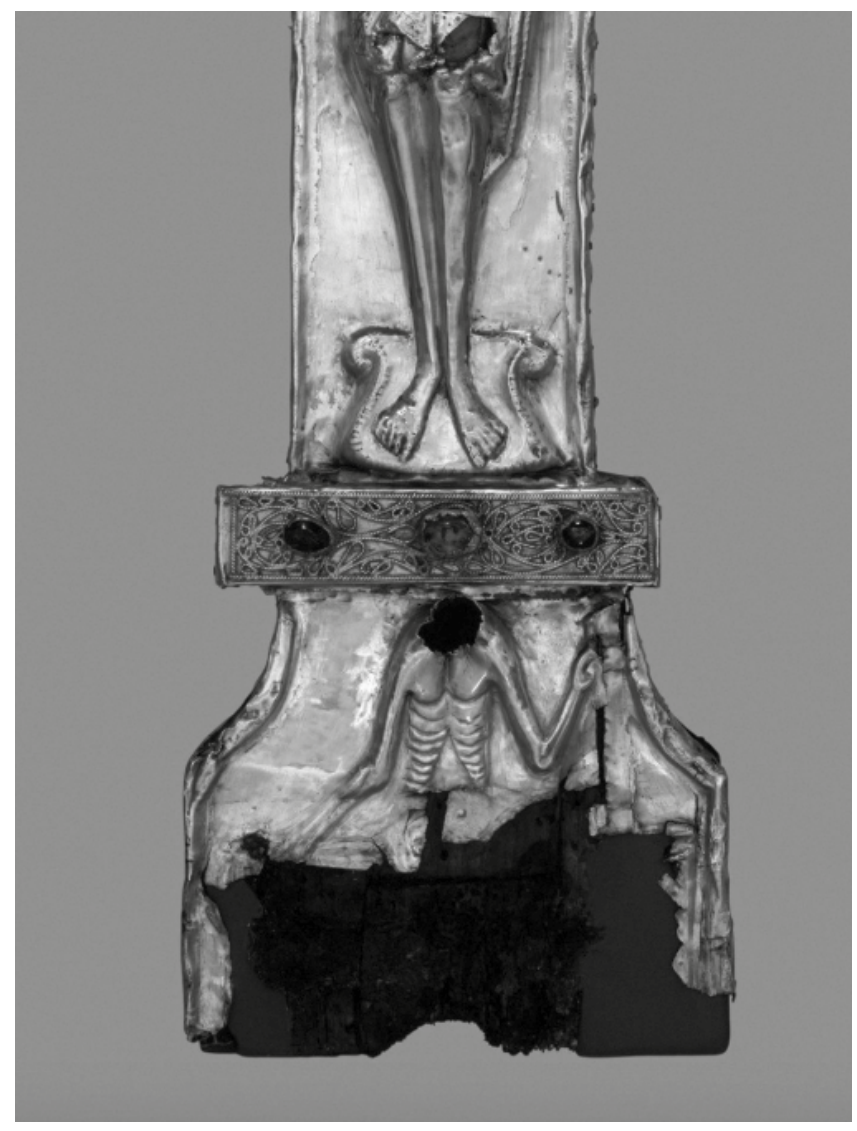

(C) Metropolitan Museum of Art, New York.

\footnotetext{
16 Tonnochy 1937, 47-49.

17 Revelation 8,3-4.
}

On the lower arm of the Fuentes Cross, now severely damaged, the figure of a resurrected Adam emerges from his tomb as a symbolic promise to churchgoers. ${ }^{18}$ The death of Christ on the Cross represented above signified the beginning of a redeeming process that will bring salvation to humankind. According to some popular fourth-century writings, such as St Jerome's in particular, the Mount Golgotha on which Christ was crucified was also the final resting place of Adam, the First Man. ${ }^{19}$ In the visual arts of the tenth century this Biblical prefiguration occasionally took the shape of a human figure emerging from a tomb at the feet of the Cross, such as in the Gerona Beatus. ${ }^{20}$ In others, such as the Angers Breton Gospels, only a head or a skull were represented. ${ }^{21}$ In the Fuentes Cross, the Apocalyptic message of imminent doom, repentance, judgement, and salvation initiated with the angel carrying the thurible was reinforced by this portrait of Adam below. Just like him, Sancha and other attendants to the liturgical services that saw the handling and parading of the Fuentes Cross visualised the resurrection of the flesh of a man so strongly emphasised during the rituals and received an individual assurance of a new life after death.

The retro of the Metropolitan Museum's cross-reliquary displays an explicit combination of elements that also highlighted this visual narrative of loss and promise that led to the Final Judgement in the minds of audiences in medieval Fuentes. The representation of the Agnus Dei acted as a direct and intentional counterpart to Christ on the front. The sacrificed Lamb of God, which carries a book, was understood by this public to have a redeeming nature, as emphasised during the Mass ritual by the well-known Agnus Dei qui tollis peccata mundi rubric. ${ }^{22}$ Nonetheless, the contiguous appearance of the four symbols of the Evangelists, as well as the inscription displaying the name of the object's patroness, openly connected all these elements to the wider perception and significance of the Fuentes Cross. Firstly documented in the mid-ninth-century Moutier-Grandval Bible, the decades around the year 1000 witnessed the apparition of several representations on parchment and ivories of an Agnus Dei at the centre of schematic compositions of crosses or circles also portraying the four symbols of the Evangelists on each side. Manuscripts from Fulda, St Gallen, and an ivory panel from Salerno, attest to this iconographic development elsewhere in Europe. ${ }^{23}$ In symbolic terms, the process initiated by the death of Christ on the Cross was achieved by the Last Judgement and the several visions that St John of Pathmos had of the Lamb of God and the Tetramorph. The name of Sancha next to these images thus reverberated as the individual behind the commission of such a luxurious, complex, and useful liturgical tool. When the time came, the churchmen, the local audience at Fuentes, and Christ would have remembered Sancha's deeds, who, just as Adam, would also re-emerged from her burial place.

18 Keshman-Wasserman 2015, 13-18.

19 Krewson 2017, 125-127.

20 Gerona, Archivo de la Catedral, MS. 7, f. 16v.

21 Angers, Bibliothèque municipale, MS. 24, fol 7v. See Kitzinger 2018, 155.

22 Mazza 1999, 267.

23 Cherry 2003, 171-172. 
This explicit narrative of salvation was thus only fully visible to the congregation when the Fuentes Cross was not fixed hanging on a wall at San Salvador, for instance, on the central apse's wall, above the trifora arch right behind the altar. If, instead, suspended from the church's chancel arch, only the clergy and assistants around the altar would have got a glimpse of the reverse of the crucifix. In Ottonian Cologne, the Gero Cross was assumed to have been permanently fixed. In the case of the Fuentes Cross, that circumstance is therefore open to discussion. Parading the crucifix was intrinsically necessary for the whole understanding of the complex visual narration to which the imagery referred. Unlike Cologne Cathedral, the church of San Salvador at Fuentes was a much smaller and perhaps less formal setting for the display of the New York crucifix. Parading the escathological messages of the Fuentes Cross was substantially easier and their moving narratives probably reinforced the communal piety of the congregation on special liturgical occasions.

\section{PERFORMING REDEMPTION}

If the Fuentes Cross was paraded across the interior, and probably the exterior, of the church of San Salvador and nearby locations in the late twelfth century, it did so regularly but not frequently. A scattered local population perhaps meant a fluctuating audience for the Fuentes liturgy and less need for the constant handling of the luxurious crossreliquary, especially outdoors, under the often inclement weather of the Asturias region. Inside San Salvador, the local clergy perhaps handled and paraded the crucifix on the Sunday Mass or, most likely, during Easter, the Feast of the Cross in September, or the dies natalis and related festivities of the unknown saint whose relic the Fuentes crucifix contains.

As previously seen in Ottonian Cologne, some of the proceedings of the regular Mass established a clear symbolic link with Gero's crucified Christ. ${ }^{24}$ As Fisher pointed out, the presence of the cross highlighted in particular the consecration of the Host. Moreover, if actually painted in the late tenth century, any of the stigmata of Christ would have also openly referred to the Eucharistic wine. In the case of Fuentes, the Agnus Dei of the reverse of the crucifix also referred to the eponymous rubric of the Mass and the concept of sacrifice. Due to the processional nature of the Asturian crucifix, it is finally possible to imagine the Fuentes Cross being also paraded as part of the Offertory procession that, at the beginning of the Eucharist, witnessed the ceremonial presentation of the Host and chalice of wine that assistants carried from the sacristy, or the church's entrance, to San Salvador's altar.

Fisher's 2006 contribution also stressed the potential perception of the Gero Cross during the Easter season at Cologne, a performative phenomenon intended to re-enact to some extent the Gospel narration that Fisher labelled a "play". ${ }^{25}$ The suspended crucifix may have been veiled during Lent, especially if located above or behind the main altar. ${ }^{26}$ On Easter Friday, during the so-called Adoration of

\footnotetext{
24 Fisher 2006, 50-51.

25 Ibidem 50

26 Van Tongeren 1999.
}

the Cross, the Gero crucifix would have been subsequently deposed on the altar and perhaps covered as re-enacting a symbolic Entombment of Christ (depositio) with the object as a performative centre. ${ }^{27}$ Finally, on Easter Sunday, the Gero Cross was likely unveiled and lifted up at the altar (elevatio), therefore celebrating Christ's Resurrection for the awe and joy of the attending Cologne assembly. ${ }^{28}$ Even though the weekly use of the Fuentes Cross on Sundays remains hypothetical, the Easter liturgical scenario of Cologne is also perfectly plausible in Asturias two hundred years later. The Easter celebrations in the parish and the existence of a relic probably attracted not only a vast majority of the local rural population, but also visitors from Villaviciosa and other nearby parishes and valleys. The importance of these annual Eucharistic services, which were at the centre of the liturgical calendar of entire communities, was such that the use and display of the Fuentes Cross somehow appears natural. Just as in Cologne, the Fuentes cross-reliquary was perhaps veiled, deposed, and lifted up following the sequence of events in the Gospels and in a close performative relation with the main altar of the church.

Another important feast that may have been celebrated at Fuentes is the Exaltation of the Cross. ${ }^{29}$ Early Italian manuscript materials for this feast, which was celebrated in September, stress the redemptive importance of the Eucharistic sacrament in order to attain salvation and the fundamental nature of Christ's death, which, according to Van Tongeren, was halfway between the mystery and a sign to be recognised. ${ }^{30}$ Other early materials emphasised instead the parallels between Christ and Adam, which in the Fuentes Cross is in fact an explicit visual relationship, and the altar of the church as a place for sacrifice, as understood in Cologne. ${ }^{31}$ In most traditions, some of these prayers of the Exaltatio service also requested the continuous intervention of God and the protection for the assembly against evil through the symbol of the Cross. Van Tongeren also lists a number of Hispanic sources, dating from the tenth and eleventh centuries, as evidence of the introduction and subsequent popularity of the feast in the north of the Iberian Peninsula over this period. ${ }^{32}$

Finally, the Fuentes Cross was very likely displayed and perhaps paraded as part of the Offertory procession on the day that commemorated the anniversary of the death of the saint whose remains were kept inside the silver crucifix. ${ }^{33}$ In addition to textual addenda to the normal proceedings of the Mass, the dies natalis of the saint in question probably witnessed a higher than usual number of visitors to the Fuentes parish and the extraordinary religious fervour of a pious crowd that aimed to interact physically with the object, through rubbing and kissing. During the liturgical year, other minor festivities or anniversaries may have also witnessed popular processions involving the display of the Fuentes Cross, such as Palm Sunday. Due to the short distance, the silver crucifix was perhaps taken in solemn pro-

\footnotetext{
Fisher 2006, 51.

28 Van Ausdall 2012, 549.

29 Van Tongeren 2000.

30 Ibidem, 83-84.

Ibidem, 87-89.

Ibidem, 253-259.

Vauchez 1997, 19-21.
} 
cession to the town that later became Villaviciosa, roughly one kilometre away, or to the nearby San Salvador de Valdedios monastery, just outside this growing urban nucleus.

\section{A SHINING VISION}

Over recent years, the study of materiality in medieval liturgical contexts has enjoyed major breakthroughs. The work of specialists such as Herbert Kessler, Caroline Walker-Bynum, Aden Kumler, Ittai Weinryb and Bissera Pentcheva, has unveiled a vast quantity of medieval objects and sources that permit today consideration of the connotations that materials associated with the sacred once had for pious audiences. ${ }^{34}$ From this perspective, the Fuentes Cross offers unique research perspectives. The repousse decoration and the silver plaques, plus the gilding applied to some parts, the gems, the filigree, the ancient engraved stones, and the actual wood of the core, possessed their own meanings for the learned. This wood core was also home to a still unidentified relic wrapped in a tissue, which added another level of material significance to the handling of the Fuentes Cross in the late twelfth century.

Silver had been a common commodity in the Iberian Peninsula since Roman times and was extracted especially across the southern Baetica province, an activity that continued well into the Visigothic and Andalusi periods. ${ }^{35}$ In the northern Asturias region, the numerous mines of the Salas area, roughly forty kilometres away from Villaviciosa, also witnessed the extraction of this material and silver circulated overall widely especially as coinage in medieval Iberia. ${ }^{36}$ It is unclear where the silver for the Fuentes Cross actually came from, whether it was imported or obtained within certain geographical limits. The addition of gilding, filigree, gems, and precious stones of Roman origin definitely attest to a substantial economic power and a certain level of logistics on behalf of the object's patroness, Sancha. In one way or the other, silver was clearly available in Asturias as a material for important liturgical objects, since the Arca Santa chest-reliquary in Oviedo Cathedral, created in the late eleventh century, was also made of silver repousse in the outside. ${ }^{37}$

As a medieval material full of agency, silver has not attracted the same level of attention than gold. As Kessler remarks in his seminal contribution to the study of silver's materiality, Bede the Venerable or St Gregory the Great commented on the agency of the metal, with the Roman Pontiff mentioning in his Moralia in Job that "Sacred speech is mostly compared to silver [...] because they (the objects) shine with the splendour of the virtues of the Father ....".38 By the time the Fuentes Cross was perhaps being made, the French monk and author Thomas of Perseigne, also quoted by Kessler, related the duality gold/silver to Christ's dual nature, further explaining that refining silver established a par-

\footnotetext{
34 Kessler 2011; Walker-Bynum 2011; Kumler and Lakey 2012; Weinryb 2013, 2016, 2018.

35 Raddatz 1969; Domergue 1990; Blázquez 1996

36 Santos Yanguas and Cartes Hernández 2002-2003. See also Fernández Ochoa 1979.

37 Little, Dodds and Williams 1993, 259-260 (n. 124). Harris 1995, 83-85.

38 Kessler 2011, 54-55.
}

allel with purging one's sins. ${ }^{39}$ It is also around the year 1200 when some major European reliquaries representing bodily parts, such as the Osnabrück arms or the head of St Maurice of Agaune, used silver plaques as skin or fabric, whereas gold or gilding were used instead to highlight important elements, as in the case of the Fuentes Cross. ${ }^{40}$ In the literary traditions of the Iberian Peninsula itself, the writings of St Isidore of Seville devoted little attention to the metal in comparison to gold, bronze, or even precious stones of different colours. His analysis in the early seventh-century Etymologies (Book XVI, De lapidibus et metallis, xix) is remarkably short and soon shifts to discuss mercury within the same section, entitled though De argento..$^{41}$ However, in St Isidore's History of the Goths, gold and silver are again given equal importance as the materials of church treasures at St Peter's in the last days of the Roman Empire..$^{42}$ Beyond the notion of true material luxury, these symbolic connotations of silver probably appealed to both the clergy and the congregation at Fuentes in the late twelfth century.

Just as the perception of the retro of the crucifix displaying the Agnus Dei depended on the location of the object inside the church of San Salvador, the appreciation of the material qualities of the Fuentes Cross also appeared connected to both movement and light conditions. During the Offertory procession during certain Masses, perhaps the single most common occasion during which the object was handled, the Fuentes Cross was probably paraded from a lateral space or, more likely, from the building's entrance to the central aisle, across the central corridor, and to the church's main altar. Even though the exact appearance of the interior of San Salvador in the late twelfth century is exactly unknown, it is plausible that, due to the lack of wide apertures in the walls, the Offertory procession, the rest of the Eucharist, and other liturgical ceremonies inside the building occurred often in an atmosphere of dimmed light. ${ }^{43}$ Lamps, candlelights or large candelabra were therefore necessary items for the normal performance of the Mass and the reading of the Scriptures. In these circumstances, the fires of the candles shone on the surface of the Fuentes Cross generating visual effects that, especially when paraded across the central aisle, likely evoked living matter, such as moving waters. ${ }^{44}$ This phenomenon did not only apply to silver, but also to the gilding that highlighted attributes such as Christ's crown, or the red gems that infused the eyes of the figure of Christ of a special agency that mystified the congregation during the liturgical services at Fuentes.

\section{PATRONAGE AND COMMUNITY}

The richness of the Fuentes Cross was an ambitious artistic command that primarily fulfilled a liturgical role in the eponymous parish of the Villaviciosa area. This crucifix-reliquary in New York represented at the same time a societal expression, an example of magnificentia that benefited di-

\footnotetext{
39 Ibidem 54.

40 Hahn 2012, 39-40.

41 Barney 2006, 330.

42 Wood 2012, 191.

43 Rodríguez Viejo 2017, 136-146.

44 Carbon and Deininger 2013. See also for Byzantium, Pentcheva 2010, 136-137.
} 
rectly both the local Church and the patroness, the noblewoman Sancha, at a time of remarkable civil and ecclesiastical growth in the region.

The modern town of Villaviciosa is located roughly forty kilometers away from Oviedo, the region's capital and seat of an important historical diocese. ${ }^{45}$ Previously a small port at the bottom of an estuary leading to the Bay of Biscay, the nucleus of Villaviciosa grew throughout the twelfth and thirteenth centuries as a harbor and a trade meeting-point to become a chartered town by 1270 , then Puebla de Maliayo. ${ }^{46}$ Well before that date, monastic foundations, agricultural villas, and churches flourished in the hills and valleys around the nucleus. The area was known for the cultivation of apples, the farming of cereals and fruits, as well as animal husbandry. ${ }^{47}$ Outside the urban core of what became Villaviciosa stood the monastery of San Salvador de Valdediós, a royal foundation from the late ninth century whose church is better-known as one of the most celebrated examples of Asturian pre-Romanesque architecture. After the capital of the Asturian kingdom was moved from Oviedo to León in 911, the monarchy also sponsored the construction of San Salvador de Priesca (923), a large church built in the same style barely five kilometres away. In addition to these important foundations, the landscape around Villaviciosa was also filled with many estates owned by the local nobility, many of which also enjoyed the existence of a small church that acted as both family chapel and a parish hub for the neighbourhood (a so-called villa cum ecclesia).

This was probably the ultimate origin of the church of San Salvador at Fuentes, now a district integrated into the town of Villaviciosa itself. Located on a hill nearby, an inscription on the jambs of one of the entrances to the building states that a family made of a husband and a wife, Diego Pepici and Mansuara, together with the man's mother, Vistrildi, founded the church in 1021 so it could be used "for generations to come". ${ }^{48}$ Two years later, the church was dedicated to the Holy Saviour by the Bishop of Oviedo, Adaganeo (1013-1025), who seemingly visited the site exclusively to visit the building and perform the necessary dedication rites. As a matter of fact, the church bore the same dedication to the Holy Saviour than Oviedo Cathedral itself, as well as the nearby pre-Romanesque church of Valdediós and the church at Priesca, all the result of earlier patronage associated with the Asturian monarchy. Moreover, either the Oviedo prelate or Pepici's family arranged for the new church to contain also a number of relics, ostensibly brought from Oviedo. ${ }^{49}$ In this range of unspecified relics was probably found the unknown material later wrapped in a tissue and put inside the Fuentes Cross in New York. The foundation of San Salvador at Fuentes is certainly remarkable as an enterprise initiated by a local, perhaps land-owning family, which nonetheless soon enjoyed not only the seal of approval by the regional diocese, but also a number of relics probably aimed at somehow quickly creating a brand-new ecclesiastical hub in the area.

\footnotetext{
45 Solano Fernández-Sordo 2016, 39-53.

46 Ibidem, 383-385.

47 Ibidem, 318-336.

48 Ruiz de la Peña 2001, 358. Solano Fernández-Sordo 2016, 164 -

49 Ibidem, 165
} 165.
Sancha Gundisalvo's artistic command, one hundred and fifty years later or so after the foundation of the church, therefore represented a continuation of this trend of constructions and patronage by the local nobility. It is a possibility to imagine Sancha as being a descendant of the Pepici, who eventually came to own the entirety or part of their agricultural estates and possessions. In the late twelfth century, only a reference to a certain "Gundisalvo" appears in local documentation. As Solano Fernández-Sordo lists, a Castilian nobleman, Count Gundisalvo of Burova, was registered in a charter from 1179 as living in what was then Villaviciosa and working for the regional governor. ${ }^{50}$ Since "Gundisalvo" (Gonzalo in modern Spanish spelling) can be either a name or a surname, it is difficult to find the relationship between the two individuals who, however, lived contemporaneously in the same local area. Based on social extraction, it is perhaps a reasonable hypothesis to conceive that a prominent local noblewoman married a well-connected newcomer from Castile working in the administration.

Sancha's patronage initiative in the late twelfth century increased the importance of the San Salvador church and the Fuentes parish. San Salvador was one of the twentyseven documented church and monastic foundations that took place in the region between the early eleventh and early thirteen centuries. Moreover, the church found by the Pepici boasted a number of relics that, added to the luxurious silver cross-reliquary commissioned by Sancha later on, surely attracted a constant flow of local, regional, and perhaps even international visitors. The Villaviciosa area is in fact still located roughly half-way across the Northern Route of El Camino (St James' Way) that runs through Spain's Atlantic coast to Santiago de Compostela, and represented a major stop-over before the pilgrims arrived in Oviedo. ${ }^{51}$

A few important questions remain. The logistics behind the creation of the silver cross-reliquary are unclear, this local area being perhaps too small to host a silversmithing workshop of renown. Since silver had been worked in or near Oviedo for the production of the Arca Santa chestreliquary, it is plausible to imagine an active workshop in the regional capital, somehow attached to the diocese, perhaps answering Sancha's request. Secondly, this lavish item was used at Fuentes and perhaps in nearby local areas on special occasions, but the visit and presence of the Bishop of Oviedo, whose institution showed signs of a close relationship with Fuentes in particular and the relics there located, is also uncertain. Liturgy, processions, and devotion at Fuentes occurred independently, through local clergy, but it is an option to also imagine successive Oviedo prelates paying an occasional visit to Fuentes, perhaps on the dies natalis of the saint venerated there who was deemed important enough to have a relic inserted inside the silver cross. Finally, it is also likely to conceive the Fuentes Cross and its inscription as being back then in close relation to Sancha's resting place after her passing. In Ottonian Cologne, the Gero Cross had been located at some stage inside the archbishop's funerary chapel as recorded by Thietmar, perhaps after the prelate's death. Even though the two cases are entirely different, Sancha may have been buried somewhere

50 Ibidem, 203.

51 Damme 2014. See also Solano Fernández-Sordo 2016, 169. 
in or near the church of San Salvador. This burial at Fuentes echoed the piety and ambition that she showed by commissioning one of the most luxurious examples of metalwork in the Spanish Romanesque.

\section{BiBLIOgRAFíA}

Álvarez Martínez, María Soledad. 1993. «Espacio sagrado y ajuar litúrgico. San Salvador de Fuentes». In Orígenes. Arte y cultura en Asturias, siglos VII - XV, edited by María Cruz Morales Saro, 303-311. Madrid: Lunwerg Editores.

Arbeiter, Achim and Sabine Noack-Haley. 1999. Christliche Denkmäler des frühen Mittelalters vom 8. bis ins 11. Jahrhundert. Mainz: Philipp von Zabern Verlag.

Balbín Loredo, Rafael. 1996. La cruz de Fuentes (Villaviciosa). Villaviciosa: Cubera.

Barney, Stephen. 2006. The Etymologies of Isidore of Seville. Cambridge: Cambridge University Press.

Belting, Hans. 2001. Bild-Anthropologie. Entwürfe für eine Bildwissenschaft. Munich: Wilhelm Fink Verlag.

Blaauw, Sible de. 2001. «Following the Crosses: The Processional Cross and the Typology of Processions in Medieval Rome». In Christian Feast and Festival: The Dynamics of Western Liturgy and Culture, edited by Paul Post, Gerard Rouwhorst, Louis Van Tongeren and Ton Scheer, 319-343. Leuven: Peeters.

Blázquez, José María. 1996. «Las explotaciones mineras y la romanización de Hispania». In La romanización en Occidente, edited by José María Blázquez and Jaime Alvar, 179-200. Madrid: Cátedra.

Brown, Peter. 1981. The Cult of the Saints: Its Rise and Function in Latin Christianity. Chicago: Chicago University Press.

Carbon, Claus-Christian and Pia Deininger. 2013. «Golden Perception. Simulating Perceptual Habits of the Past». i-Perception 4: 468-476. https://doi.org/10.1068/i0605

Cherry, John. 2003. "Containers for Agnus Deis». In Through a Glass Brightly. Studies in Byzantine and Medieval Art and Archaeology Presented to David Buckton, edited by Charles Entwistle, 171-183. Oxford: Oxford University Press.

Cid Priego, Carlos. 1996. Orfebrería románica. El arte en Asturias a través de sus obras. Oviedo: Prensa Asturiana.

Damme, Astrid Van. 2014. "Peregrinación a Santiago y Oviedo por la ruta costera en la Edad Media». Estudios Medievales Hispánicos 3: 173-206.

Domergue, Claude. 1990. Les mines de la Péninsule Ibérique dans I'Antiquité romaine. Rome: École Française de Rome.

Fernández Conde, Javier. 1994. La época de Alfonso III y San Salvador de Valdediós. Oviedo: Universidad de Oviedo.

Fernández Ochoa, Carmen. 1979. «Aportación al estudio de la minería romana en Asturias: El dique de la Barrosa y el Canal de los Lagos de Silva de Salave (Tapia de Casariego)». Boletín del Instituto de Estudios Asturianos 96-97: 411-422.

Fisher, Annika. 2006. "Cross Altar and Crucifix in Ottonian Cologne: Past Narrative, Present Ritual, Future Resurrection». In Decorating the Lord's Table: On the Dynamics between Image and Altar in the Middle Ages, edited by Soren Kaspersen and Erik Thuno, 43-62. Copenhagen: Museum Tusculanum.

Franco Mata, María Ángela. 2009-2010. «Tesoros de Oviedo y León: Problemas estilísticos, liturgia e iconografía». Boletín del Museo Arqueológico Nacional 27-28: 83-85.

García de la Borbolla, Ángeles. 2014. «Reliquias y relicarios: una aproximación al estudio del culto de los santos en la Navarra medieval». Hispania Sacra LXVI: 89-118. https://doi.org/10.3989/hs.2014.086

Hahn, Cynthia. 2012. Strange Beauty: Issues in the Making and Meaning of Reliquaries, 400 - circa 1204. University Park: Pennsylvania State University Press.

Harris, Julie. 1995. «Redating the Arca Santa of Oviedo». The Art Bulletin 77 (1): 82-93.
Kawamura, Yayoi. 1994. "La Cruz de Sales y algunas consideraciones sobre las cruces románicas de metal en Asturias». Boletín del Real Instituto de Estudios Asturianos 144: 666-677.

Keshman-Wasserman, Anastasia. 2015. «The Cross and the Tomb: the Crusader Contribution to the Crucifixion Iconography». Between Jerusalem and Europe: Essays in Honour of Bianca Kühnel, edited by Renana Bartal and Hannah Vorholt, 13-33. Leiden-Boston: Brill.

Kessler, Herbert. 2011. "The Eloquence of Silver». In L'allégorie dans l'art du Moyen Age. Formes et fonctions. Héritages, créations, mutations, edited by Christian Heck, 49-64. Turnhout: Brepols.

Kingsley, Jennifer. 2011. «Picturing the Treasury: The Power of Objects and the Art of Memory in the Bernward Gospels». Gesta 50 (1): 19-39. https://doi.org/10.2307/41550547

Kingsley, Jennifer. 2014. The Bernward Gospels: Art, Memory and the Episcopate in Medieval Germany. University Park: Pennsylvania State University Press.

Kitzinger, Beatrice. 2018. «Representing the Gospels beyond the Carolingian Center». In Imago libri. Représentations carolingiennes du livre, edited by Charlotte Denoël, Anne-Orange Poilpré and Sumi Shimahara, 151-161. Turnhout: Brepols.

Kitzinger, Beatrice. 2019. The Cross, the Gospels, and the Work of Art in the Carolingian Age. Cambridge: Cambridge University Press.

Krewson, William. 2017. Jerome and the Jews: Innovative Supersessionism. Eugene: Wipf and Stock.

Kumler, Aden y Christopher Lakey. 2012. «Res et Significatio: The Material Sense of Things in the Middle Ages». Gesta 51 (1): 1-17. https://doi.org/10.1086/669944

Little, Charles. 1993. "Cruz procesional de San Salvador de Fuentes». In Orígenes. Arte y Cultura en Asturias, siglos VII-XV, edited by María Cruz Morales Saro, 307. Madrid: Lunwerg Editores.

Little, Charles, Jerrilynn Dodds and John Williams, eds. 1993. The Art of Medieval Spain, A.D. 500-1200. New York: Publications of the Metropolitan Museum of Art.

Martin Ansón, María Luisa. 1994. "La importancia de las reliquias y tipología de relicarios en el Camino de Santiago en España». Anales de Historia del Arte 10: 793-804.

Mazza, Enrico. 1999. The Celebration of the Eucharist. The Origin of the Rite and the Development of its Interpretation. Collegeville: Liturgical Press.

Morais Morán, José Alberto, 2013. «La imagen de la desaparecida Ara de Obona (Asturias) en el contexto de la orfebrería románica asturleonesa». Codex Aquilarensis 29: 223-250.

Moralejo Álvarez, Serafín. 1982. "Les arts somptuaires hispaniques aux environs de 1100 ». Les Cahiers de Saint-Michel de Cuxa 13: 289-290.

Munns, John. 2016. Cross and Culture in Anglo-Saxon England: Theology, Imagery, Devotion. Cambridge: Cambridge University Press.

Pentcheva, Bissera. 2010. The Sensual Icon: Space, Ritual, and the Senses in Byzantium. Pensilvania: Pennsylvania State University Press.

Raddatz, Klaus. 1969. Die Schatzfunde der Iberischen Halbinseln vom Ende des dritten bis zur Mitte des ersten Jahrhunderts vor Chr. Berlin: De Gruyter:

Rodríguez Viejo, Jesús. 2017. «Faith on Parchment. Approaches to Sensorial Perception in two Ottonian Illuminated Manuscripts from St Gall». Concilium Medii Aevi 20: 129-167.

Ruiz de la Peña, Isabel. 2001. "La arquitectura religiosa en Asturias en torno al año 1000». In La Península lbérica en torno al año 1000, edited by Eloy Benito Ruano. Ávila: Fundación Sánchez Albornoz.

Santos Yanguas, Narciso Vicente y Emilio Cartes Hernández. 20022003. "Los orígenes históricos del concejo de Salas (Asturias): Cultura castreña y minería romana del oro». Memorias de Historia Antigua 23-24: 193-237.

Saxon, Elizabeth. 2012. "Carolingian, Ottonian, and Romanesque Art and the Eucharist». In A Companion to the Eucharist in the Middle Ages, edited by Levy, lan Christopher, Gary Macy, and Kristen van Ausdall, 251-324. Leiden: Brill. 
Silva y Verástegui, Soledad de. 2009. «Los sepulcros de los santos: la piedad medieval, el sentido del decoro, y el ornato durante los siglos del Románico». Edad Media 10: 93-129.

Solano Fernández-Sordo, Álvaro. 2016. De Maliayo a Villaviciosa. Un territorio de la Marina centro-oriental de Asturias en la Edad Media. Villaviciosa: Fundación José Cardín Fernández y Ayuntamiento de Villaviciosa.

Tongeren, Louis Van. 1999. «La vénération de la croix. Le vendredi saint dans la liturgie hispanique». Questions liturgiques/Studies in Liturgy 80: 106-131.

Tongeren, Louis Van. 2000. Exaltation of the Cross: Toward the Origins of the Feast of the Cross and the Meaning of the Cross in Early Medieval Liturgy. Leuven: Peeters.

Tonnochy, Alec. 1937. "The Censer in the Middle Ages». Journal of the British Archaeological Association 2 (1): 47-62.

Van Ausdall, Kristen. 2012. "Art and Eucharist in the Middle Ages» In A Companion to the Eucharist in the Middle Ages, edited by lan Christopher Levy, Gary Macy, Kristen van Ausdall, 541-617. Leiden: Brill.
Vauchez, Andri. 1997. Sainthood in the Later Middle Ages. Cambridge: Cambridge University Press.

Walker-Bynum, Caroline. 2011. Christian Materiality. An Essay on Religion in Late Medieval Europe. New York: Zone Books.

Warner, David. 2001. Ottonian Germany. The Chronicle of Thietmar of Merseburg. Manchester: Manchester University Press.

Weinryb, Ittai. 2013. "Living Matter: Materiality, Maker and Ornament in the Middle Ages». Gesta 52 (2): 113-132. https://doi. org/10.1086/672086

Weinryb, Ittai. 2016. The Bronze Object in the Middle Ages. Cambridge: Cambridge University Press.

Weinryb, Ittai. 2018. "Hildesheim Avant-garde: Bronze, Columns, and Colonialism». Speculum 98 (3): 728-782. https://doi. org/10.1086/698705

Wood, Jaime. 2012. The Politics of Identity in Visigothic Spain: Religion and Power in the Histories of St Isidore of Seville. Leiden - Boston: Brill. 